\title{
Acranthera sinensis C. Y. Wu (Rubiaceae): A NEW DISTRIBUTIONAL RECORD FROM VIETNAM
}

\author{
Bui Hong Quang ${ }^{1 *}$, Nguyen Sinh Khang ${ }^{1}$, Vu Tien Chinh ${ }^{1}$, Nguyen Quang Hieu ${ }^{2}$ \\ ${ }^{1}$ Institute of Ecology and Biological Resources, VAST, *bhquang78@gmail.com \\ ${ }^{2}$ Center for Plant Conservation, VUSTA
}

\begin{abstract}
Acranthera sinensis C.Y. Wu (Rubiaceae), previously known only from China, is newly recorded from Vietnam. A morphological description and color illustrations, morphological comparison of Acranthera sinensis with Acranthera siamensis, together with short notes, map on the distribution, ecology, habitat and conservation of the species are provided.
\end{abstract}

Keywords: Rubiaceae, Acranthera, A. sinensis, new record, Vietnam.

\section{INTRODUCTION}

This species Acranthera sinensis C. Y. Wu, under the family Rubiaceae, was so far known to be endemic to China, according to the Chen. T., et al [1]. During a field trip to the Ha Giang province (North Vietnam), an interesting species of Rubiaceae was encountered. Hence, we report this species as a new distributional record to the flora of Vietnam, with a single population found in the primary broad-leaved evergreen closed forest, nearby waterfall, in Ha Giang province, not common in the studied areas. More extensive field surveys are needed to find more Acranthera sinensis populations that probably exist somewhere in similar habitats in the studied areas. This work will provide insight for conservation and management of rare and threatened plant species in Vietnam. The taxonomic description and color photographs, distribution, ecology, phenology and conservation of the species are provided to facilitate its easy identification (fig. 1, fig. 2). This species is morphologically most similar to Acranthera siamensis (Kerr) Bremek, in having erect subshrub to $1 \mathrm{~m}$ tall, leaves membranaceous, elliptic to obovate. However, this species can be differentiated from the said species in having lateral veins 9-11 pairs (vs 6-9 pairs) inflorescence 1-flowered (vs 5-20 flowered and calyx lobes cylindrical to obconical, 3-4 cm long (vs lobes lanceolatelinear, 8-9 mm long). Species Acranthera siamensis was so far known to be endemic to Thailand, according to the Puff et al. (2005) [5] is provided (table 1).

\section{MATERIALS AND METHODS}

The collected specimens of $A$. sinensis were thoroughly processed using standard preservation methods and deposited in the herbaria, After examining all the specimens of A. sinensis kept at (CPC) Center for Plant Conservation and (HN) Institute of Ecology \& Biological Resources (HN), Ha Noi, Vietnam, ten specimens collected in 2013 from Ha Giang province, Vietnam. Photographs of the type specimens housed in the virtual herbaria (PE, IBSC) of China were also studied.

\section{RESULTS AND DISCUSSION}

Acranthera sinensis C.Y. Wu, 1957. Acta Phytotax. Sin 6 (3): 295-297, pl. 55, f. 24; Hsienshu. L, et al, 1999. Rubiaceae Fl. Rep. Pop. Sin 71 (2): 281-283.

Syntypes: China: Yunnan: 1200 m, 19 May 1934 [and 29 June 1934]: H. T. Tsai 55229 (fl.) \& H. T. Tsai 60568 (fr.) (PE photo!).

Erect subshrub to $1 \mathrm{~m}$ tall; branches generally quadrangular, densely hirsute, sparsely hairy in the younger parts; Leaves membranaceous, elliptic to obovate 9-20 × 5-10 $\mathrm{cm}$, adaxially sparsely to moderately hirsute to hispid; abaxially strigillose to strigose or hispid with pubescence denser along principal veins, base acute or cuneate, margins entire, apex acuminate or acute; lateral veins 9-11 pairs; petiole 1-7 cm long; stipules persistent, broadly 
ovate to triangular, 1-3 mm long, glabrescent, cuspidate 1-2-(3) at apex, ca. $1.5 \mathrm{~mm}$ long. Inflorescences terminal, pseudoaxillary or axillary on short shoots, 1-flowered; bracts, red lanceolate, 2-3 mm, acute. Calyx strigillose to strigose or pilose; ovary portion cylindrical to obconical, 3-4 cm; lobes linear-lanceolate, 2-4 $\mathrm{cm}$ long, erect. Corolla purple violet, inner red, calyx red-pink, funnelform, outside hirtellous to tomentulose; tube 3-4 cm; lobes ovate, 8-10 $\mathrm{mm}$, obtuse then abruptly acuminate with tip 1$2 \mathrm{~mm}$. Filaments free; anthers 5,5-10 mm, with connective spurred at apex. Ovary 5-8 mm long, 5-ridged, crowned by an indistinctly 5-lobed disk. Berry compressed cylindrical, 40-45 × ca. $5 \mathrm{~mm}$, bisulcate; seeds numerous, with testa reticulate., ca. $0.5 \mathrm{~mm}$ in diam. Fl. Apr.-Jun., fr. Jun.-Oct.

Distribution: North Vietnam: Ha Giang (Quan Ba, Tung Vai). South China (Yunnan). (fig. 1).

Ecology and habitat: Primary broad-leaved evergreen closed forest, on steep shady slope, humid area, nearby waterfall, at the elevation of 1200-1345 $\mathrm{m}$ asl.

Specimens examined: North Vietnam, Ha Giang prov., Quan Ba distr., Tung Vai comm., Thang Vill., CPC 4973 13-Apr-2013 N. Q.
Hieu, N. S. Khang, N. T. Vinh, T. B. Ngan \& N. V. Truong, near $23^{\circ} 03^{\prime} 16^{\prime \prime} \mathrm{N}, 104^{\circ} 50^{\prime} 28^{\prime \prime} \mathrm{E}$, 1345 m.a.s.l. (CPC, HN).

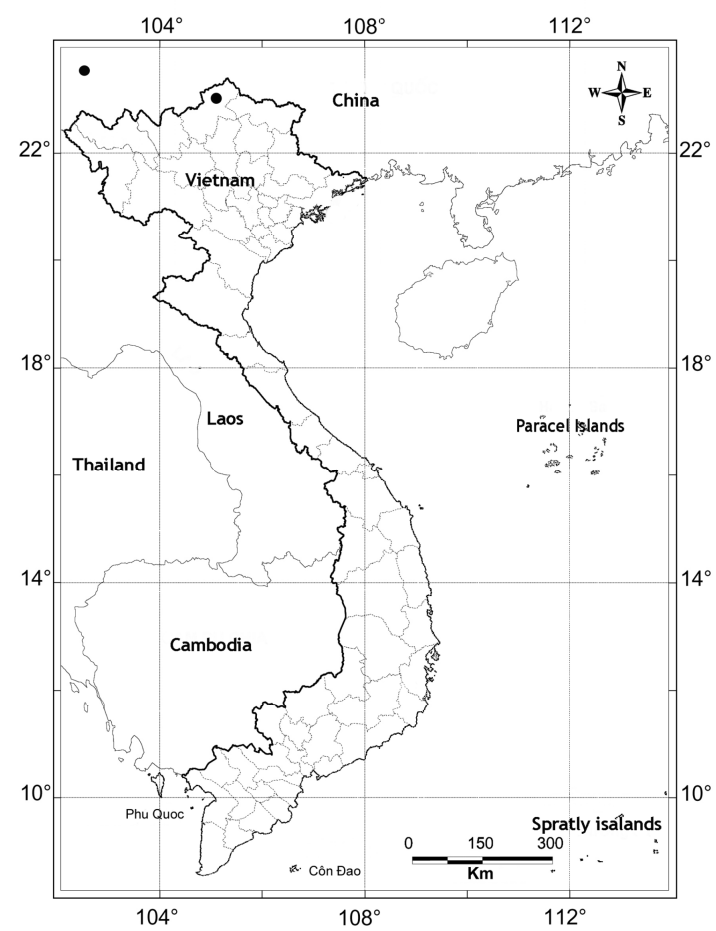

Figure 1. Distribution of A. sinensis C. Y. Wu, in Ha Giang province of North Vietnam and Yunnan province of China

Table 1. Morphological comparison of $A$. sinensis with $A$. siamensis

\begin{tabular}{|c|c|c|}
\hline Character & A. sinensis & A. siamensis $^{*}$ \\
\hline Veins & 9-11 pairs & 6-9 pairs \\
\hline Inflorescence & 1-flowered & 5-20-flowered \\
\hline Calyx & lobes cylindrical to obconical, 3-4 cm long & lobes lanceolate-linear, 8-9 mm long \\
\hline Corolla & $\begin{array}{l}\text { purple violet, inner red, calyx red-pink, } \\
\text { funnelform, outside hirtellous to } \\
\text { tomentulose; tube } 3-4 \mathrm{~cm} \text { long; lobes } \\
\text { ovate, } 8-10 \mathrm{~mm} \text { long }\end{array}$ & $\begin{array}{l}\text { greenish, pale green or greenish- } \\
\text { white, sparsely covered with short } \\
\text { adpressed hairs on the outside, } \\
\text { glabrous within, tube c. } 15 \mathrm{~mm} \text { long, } \\
\text { lobes acute, } 3 \mathrm{~mm} \text { long }\end{array}$ \\
\hline Berry & $\begin{array}{l}\text { compressed cylindrical, } 40-45 \times c a .5 \\
\mathrm{~mm}\end{array}$ & $\begin{array}{l}\text { berry-like, cylindrical, 5-ridged, c. } \\
25-30 \times 3-5 \mathrm{~mm}\end{array}$ \\
\hline Distribution & $\begin{array}{l}\text { China (Yunnam) and Vietnam (Ha } \\
\text { Giang) }\end{array}$ & Thailand (Pattani) \\
\hline
\end{tabular}

* Morphological characters following Puff et al. (2005) [5]. 


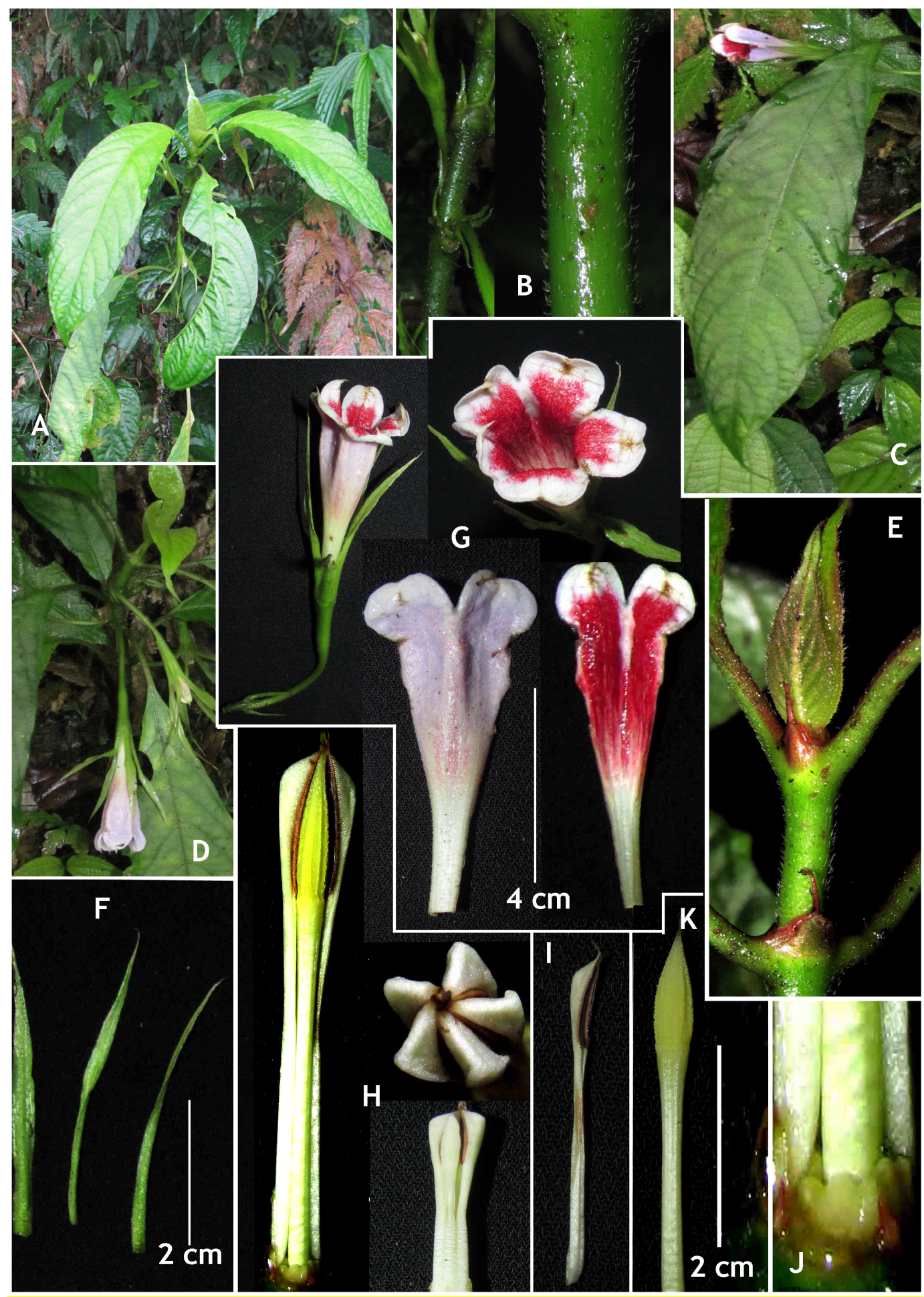

Figure 2. Acranthera sinensis C. Y. Wu

A. habit; B. stem; C. leaf; D. inflorescence; E. bracts; F. calyx; G. intact flower and corolla separated; H. filament; I. anther; K. style; J. ovary (Photo by Nguyen Sinh Khang). 
Conservation status: So far, there is a single distribution site recorded in Vietnam. The Acranthera sinensis has Area of Occupancy (AOO) estimated less than $20 \mathrm{~km}^{2}$ and number of matured individuals unknown. Moreover, this species with limitation of typical habitat characterized by primary forest, on steep shady slope, humid area, nearby waterfall, at a certain elevation (above 1000 m.a.s.l.), is not common in the studied areas. Therefore, according to the IUCN Red List criteria (IUCN, 2001) [3], Acranthera sinensis is proposed to be listed as Vulnerable under criterion D2.

\section{CONCLUSION}

Acranthera sinensis, a new record for the Flora of Vietnam, with a single population found in the primary broad-leaved evergreen closed forest, on steep shady slope, humid area, nearby waterfall, at the elevation of 1200-1345 m.a.s.l. in Ha Giang province, is preliminarily assessed conservation status of Vulnerable under criterion D2 (VU D2) [3]. More extensive field surveys are needed to find more Acranthera sinensis populations that probably exist somewhere in similar habitats in the studied areas. This work will provide insight for conservation and management of rare and threatened plant species in Vietnam.

Acknowledgments: The authors are very grateful to curators of Herbaria (HN, CPC, PE \& IBSC) for working on their collections. The authors give great thanks to authorities of $\mathrm{Ha}$ Giang province, Quan Ba district, Tung Vai commune, especially to the participants of the field survey (N. T. Vinh, T. B. Ngan \& N. V.
Truong), and people in Thang village, for providing support and kind helps.

\section{REFERENCES}

1. Chen T., Taylor C. M., Puff. C., 2011: Rubiaceae, Flora of China, in Wu C. Y., \& Raven P. H., (Eds.), Vol. 19: 1-884. Beijing Science Press \& St. Louis: Missouri Botanical Garden Press.

2. Hsienshu L., Wanchang K., Weichuiu C., Hsianghao H., Hen W., 1999: Rubiaceae, Fl. Rep. Pop. Sin., 71(2): 281-283 (in Chinese).

3. IUCN, 2001: IUCN Red List Categories and Criteria, Version 3.1. IUCN Species Survial Commission, Gland, Switzerland, and Cambridge, United Kingdom, 30 pp.

4. Phạm Hoàng Hộ, 2000: Cây cỏ Việt Nam, 3: 105-222. Nxb. Trẻ, Hà Nội.

5. Puff C., Chayamarit K., Chamchumroon V., 2005: Rubiaceae of Thailand. A pictorial guide to indigenous and cultivated genera. The Forest Herbarium, National Park, Wildlife and Plant Conservation Department, Bangkok, 10. 184 pp \& pl. 3.4.5.

6. Trần Ngọc Ninh, 2005: Rubiaceae. In: Bân, N.T., (Eds), Danh lục thực vật Việt Nam, 3: 82-157. Nxb. Nông nghiệp, Hà Nội.

7. Wu C. Y., 1957: Preliminary Report of Flora Study on Tropical and Subtropical areas, Yunnan, China. I. Acta Phytotax. Sinica. (6)3: 295-297, pl. 55, f. 24 (in Chinese). 


\title{
GHI NHậN MỚI LOÀI Acranthera sinensis C. Y. Wu (Rubiaceae) CHO HỆ THỤ̉C VẬT VIẸTT NAM
}

\author{
Bùi Hồng Quang ${ }^{1}$, Nguyễn Sinh Khang ${ }^{1}$, Vũ Tiến Chính ${ }^{1}$, Nguyễn Quang Hiếu ${ }^{2}$ \\ ${ }^{1}$ Viện Sinh thái và Tài nguyên sinh vật, Viện Hàn lâm KH \& CN Việt Nam \\ ${ }^{2}$ Trung tâm bảo tồn thực vật, Liên hiệp Các hội KHKT Việt Nam
}

\section{TÓM TẮT}

Đến nay, ở Việt Nam chưa có tài liệu nào ghi nhận chi Acranthera Arn. ex Meisn., nhưng trong thực vật chí Trung Quốc (Flora China 2011) lại ghi nhận chi Acranthera có phân bố ở Việt Nam, còn loài Acranthera sinensis $\mathrm{C}$. Y. Wu được coi là loài đặc hữu của Trung Quốc. Trong số mẫu chúng tôi thu được ở Quản Bạ, Hà Giang, tiêu bản mang số hiệu CPC 4973 lưu giữ ở phòng tiêu bản $(\mathrm{CPC})$, (HN) được xác định là loài Acranthera sinensis $\mathrm{C}$. Y. Wu, đây là loài ghi nhận mới cho hệ thực vật Việt Nam. Loài có đăc điểm hình thái: cây bụi nhỏ, phiến lá hình bầu dục; gân bên 9-11 đôi, hoa mặt ngoài hồng nhạt, bên trong họng màu đỏ. Mùa hoa, quả tháng 3-6 hàng năm. Loài $A$. sinensis được chúng tôi so sánh các đặc điểm hình thái với loài $A$. siamensis để xác định chính xác mẫu tiêu bản chúng tôi thu được là loài $A$. sinensis

Tù khóa: Rubiaceae, Acranthera, A. sinensis, ghi nhận mới, Việt Nam.

Ngày nhận bài: 11-6-2015 